\title{
Estrogen receptor alpha/beta ratio and estrogen receptor beta as predictors of endocrine therapy responsiveness-a randomized neoadjuvant trial comparison between anastrozole and tamoxifen for the treatment of postmenopausal breast
} cancer

Marcelo Madeira ${ }^{1,2^{*}}$, André Mattar ${ }^{1,3}$, Ângela Flávia Logullo ${ }^{4}$, Fernando Augusto Soares ${ }^{5}$ and Luiz Henrique Gebrim ${ }^{1,3}$

\begin{abstract}
Background: The role of estrogen receptor beta (ER- $\beta$ ) in breast cancer (BC) remains unclear. Some studies have suggested that ER- $\beta$ may oppose the actions of estrogen receptor alpha (ER- $\alpha$ ), and clinical evidence has indicated that the loss of ER- $\beta$ expression is associated with a poor prognosis and resistance to endocrine therapy. The objective of the present study was to determine the role of ER- $\beta$ and the ER- $\alpha / E R-\beta$ ratio in predicting the response to endocrine therapy and whether different regimens have any effect on ER- $\beta$ expression levels.

Methods: Ninety postmenopausal patients with primary BC were recruited for a short-term double-blinded randomized prospective controlled study. To determine tumor cell proliferation, we measured the expression of Ki67 in tumor biopsy samples taken before and after 26 days of treatment with anastrozole $1 \mathrm{mg} /$ day $(\mathrm{N}=25)$, tamoxifen $20 \mathrm{mg} /$ day $(\mathrm{N}=24)$ or placebo $(\mathrm{N}=29)$ of 78 participants. The pre- and post-samples were placed in tissue microarray blocks and submitted for immunohistochemical assay. Biomarker statuses (ER- $\beta$, ER-a and Ki67) were obtained by comparing each immunohistochemical evaluation of the pre- and post-surgery samples using the semi-quantitative Allred's method. Statistical analyses were performed using an ANOVA and Spearman's correlation coefficient tests, with significance at $p \leq 0.05$.

Results: The frequency of ER- $\beta$ expression did not change after treatment $(p=0.33)$. There were no significant changes in Ki67 levels in ER- $\beta$-negative cases $(p=0.45)$, but in the ER- $\beta$-positive cases, the anastrozole $(p=0.01)$ and tamoxifen groups $(p=0.04)$ presented a significant reduction in post-treatment Ki67 scores. There was a weak but positive correlation between the ER- $a$ and ER- $\beta$ expression levels. Only patients with an ER- $a$ /ER- $\beta$ expression ratio between 1 and 1.5 demonstrated significant differences in Ki67 levels after treatment with anastrozole $(p=0.005)$ and tamoxifen $(p=0.026)$.

(Continued on next page)
\end{abstract}

\footnotetext{
* Correspondence: marcemadeira@gmail.com

'Senology Discipline, Department of Gynecology, Federal University of Sao

Paulo-UNIFESP, R. Botucatu, 740, 04023-900 Sao Paulo, SP, Brazil

2Department of Obstetrics \& Gynecology and Women's Health of Albert Einstein Hospital, Av. Albert Einstein, 627, 05652-900 Sao Paulo, SP, Brazil Full list of author information is available at the end of the article
} 
(Continued from previous page)

Conclusions: Our results provide additional data that indicate that the measurement of ER- $\beta$ in BC patients may help predict tamoxifen and anastrozole responsiveness in the neoadjuvant setting. These effects of hormonal treatment appear to be dependent on the ratio of ER-a/ER- $\beta$ expression.

Trial registration: Current Controlled Trials ISRCTN89801719

Keywords: Estrogen receptor beta, Breast cancer, Estrogen receptor, Aromatase inhibitors/Anastrozole, Tamoxifen, Ki67, Neoadjuvant therapy, Tumor markers

\section{Background}

Breast cancer $(\mathrm{BC})$ is the most frequently diagnosed non-skin cancer among women worldwide [1-3]. The survival rate at 5 years after diagnosis in the United States has improved from $63 \%$ in the early 1960 s to $89 \%$ currently [3]. Adjuvant hormone therapy has helped achieve this substantial reduction in mortality because approximately $75 \%$ of human BCs express estrogen receptors (ERs) [4-6].

Estrogens play a central role in the development and growth of both normal and malignant mammary tissues. In addition, they mediate most of their action through the alpha ER (ER- $\alpha)$ [7]. Pathological lesions associated with increased risk of $\mathrm{BC}$ also present significantly more cells expressing ERs [8]. The ER- $\alpha$ status of breast tumors provides prognostic information and is the primary target for endocrine therapy. Effective strategies to treat ER-positive $\mathrm{BC}$ include endocrine agents that compete with estrogen for binding to its receptor, such as selective estrogen-receptor modulators (SERMs) and antiestrogens or reducing the levels of circulating estrogens by the administration of agents such as third-generation aromatase inhibitors (AIs), which have been shown to be more effective than tamoxifen in postmenopausal women in neoadjuvant and adjuvant settings [9].

The discovery in 1996 [10] of a second ER subtype, known as beta (ER- $\beta$ ), which presented different expression profiles in normal and malignant tissues, opened the possibility that breast tumors might be even more heterogeneous than originally thought. The role of ER- $\beta$ in $\mathrm{BC}$ initiation and development has not yet been clearly established [11]. In vitro experiments have demonstrated that ER- $\beta$ inhibits the proliferation, migration and invasion of $\mathrm{BC}$ cells [12-15] and the angiogenesis and growth of tumor xenografts [16]. The potential clinical use of ER- $\beta$ in BC endocrine therapy has been investigated in retrospective studies, and ER- $\beta$ positivity has been associated with significantly better survival in patients with ER- $\alpha$-negative, progesterone receptor (PgR)negative and triple-negative tumors treated with adjuvant tamoxifen therapy. These types of tumors are widely believed to be hormone unresponsive [17].

Despite initial positive responses to tamoxifen therapy, one-third of all patients will develop resistance, though their ER- $\alpha$ status may remain unchanged [18,19]. A lower expression of ER- $\beta$ is found in tamoxifen-resistant tumors, and high levels of ER- $\beta$ are occasionally associated with a better clinical outcome in ER- $\alpha$-positive breast tumors [11]. Several studies have suggested that the expression of ER- $\beta$ independently predicts a better disease-free survival in patients treated with tamoxifen [20]. However, some data have suggested that the positivity of ER- $\beta$ is associated with low cellular differentiation, which indicates that this receptor could be related to worse overall survival [21].

Data from a number of studies comparing neoadjuvant and adjuvant endocrine treatments are now available [22]. The measurement of Ki67, a cell proliferation marker, after neoadjuvant endocrine therapy can predict the efficacy of these drugs and reflect the ability of endocrine treatment to suppress proliferation [23,24]. Indeed, Ki67 levels after 2 weeks of treatment was significantly correlated with relapse-free survival in the Arimidex, Tamoxifen, Alone or in Combination trial [23,25]. However, while the expression of ER- $\alpha$ has been extensively studied as a predictive marker of treatment response, the role of ER- $\beta$ remains controversial and has never been examined in a neoadjuvant short-term trial.

In this context, the objective of the present study was to determine the role of ER- $\beta$ and the ER- $\alpha /$ ER- $\beta$ expression ratio in predicting the response to $\mathrm{BC}$ endocrine therapy with anastrozole and tamoxifen. We also focused on whether these different regimens have any effect on ER- $\alpha$ and ER- $\beta$ expression levels. Hormone receptor proteins were detected semi-quantitatively using immunohistochemistry, and we compared the expression levels of Ki67, ER- $\beta$ and ER- $\alpha$ before and after neoadjuvant shortterm treatment in postmenopausal women with invasive carcinomas.

\section{Methods}

\section{Study design, patients and treatment protocol}

We designed a randomized, prospective, controlled, double-blind study that included postmenopausal women with invasive BCs.

The eligibility criteria for the study included histologically confirmed primary stage II to III invasive BC in women who were postmenopausal, which was defined as 
no menstruation periods over the last 12 months and/or a follicle-stimulating hormone level within the postmenopausal range. The exclusion criteria were the presence of endocrine disease, metastatic disease, inflammatory $\mathrm{BC}$ (T4d), history of thromboembolism and any previous treatment for BC (surgery, radio or chemotherapy). Patients who did not comply with the prescribed medication regimen or postponed surgery were also excluded from the study. Patients who had previously taken hormone replacement therapy were included if they had stopped hormonal treatment at least 6 months prior to trial randomization.

After written informed consent was obtained, 90 patients with invasive BCs were recruited into the study and enrolled at Pérola Byington Hospital and Federal University of São Paulo Hospital, Sao Paulo, Brazil, between October 2010 and May 2012. The first tumor sample was obtained from each patient at the time of diagnosis by incisional biopsy performed in an outpatient facility using local anesthesia. A second tumor specimen was obtained from each patient during definitive surgery under general anesthesia. Both tumor samples were processed using the same paraffin-embedding technique.

The patients underwent definitive surgical treatment (modified radical mastectomy or conservative surgery with axillary evaluation) following a mean period of 26 days (range of 24-30 days and median of 26 days) after the incisional biopsy. There were 3 major protocol violations. These were performed by patients who did not take tablets correctly $(\mathrm{N}=8)$, did not proceed to surgery in time $(\mathrm{N}=3)$ or were premenopausal according to a hormone analysis $(\mathrm{N}=1)$. These patients were not included in any analyses. Seventy-eight patients with operable BCs completed the study and were randomized to receive 26 days of treatment with anastrozole $(\mathrm{N}=25)$ (1 mg/day), tamoxifen $(\mathrm{N}=24)(20 \mathrm{mg} /$ day $)$ or placebo $(\mathrm{N}=29)$ (Figure 1). Randomization and allocation to trial groups were carried out by a central computer system [26].

The study was approved by the Human Investigation Committees of Federal University of São Paulo and Pérola Byington Hospital under the process number CEP 0894/10, Brazil, and conducted in accordance with the Helsinki Declaration.

\section{Histology and tissue microarray construction}

All samples were fixed in 10\% neutral-buffered formalin, processed and embedded in paraffin. Respective paired tumor blocks containing samples obtained from all patients prior to any of the interventions and during definitive surgery were retrieved from the pathology files of our institution.

Specimen pairs were cut into 4- $\mu$ m sections, mounted on lysine-coated slides, stained with hematoxylin and eosin and examined to confirm the diagnosis of

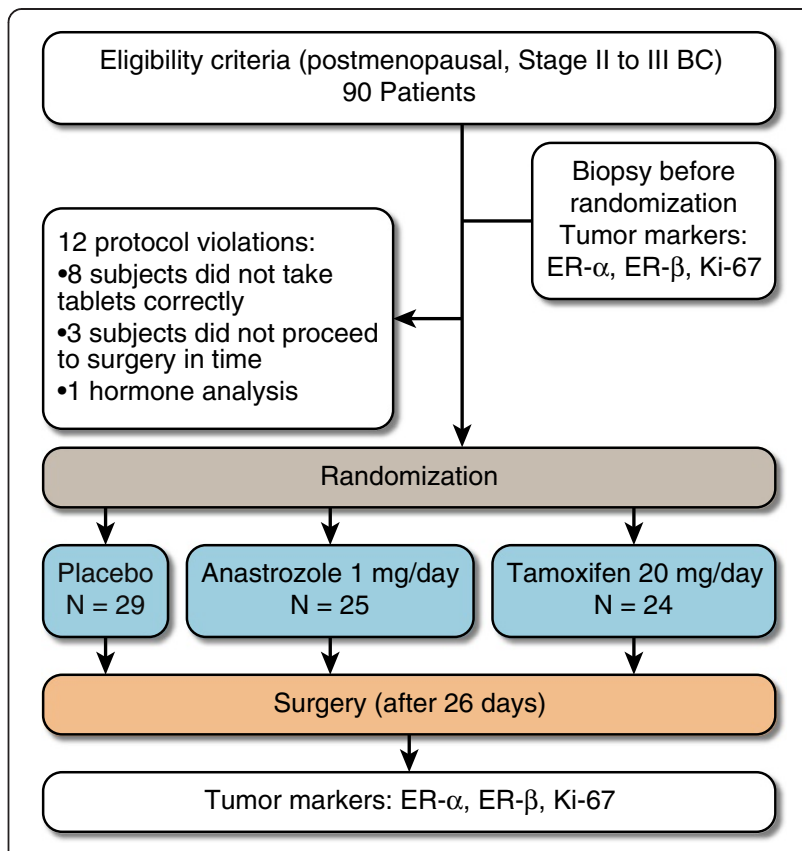

Figure 1 Trial schematic design.

carcinoma. The same slides were used by one pathologist investigator (AFL) to determine the area of interest (the most representative of the tumor) to be included in the tissue microarray (TMA) marked on the slide. Using a marking pen, the corresponding region was circled on the archival "donor" paraffin block. Tumor TMA blocks were obtained by punching 2-nm tissue cores from each donor paraffin block. The samples were then arrayed onto a recipient blank block using a manual tissue arrayer (Beecher Instruments, Sun Prairie, WI, USA) [27]. Control tissues were included in each of these paraffin blocks.

\section{Immunohistochemistry assays}

After construction, 3- $\mu \mathrm{m}$ tissue sections were cut and transferred to silanized slides and then left to dry overnight at $56^{\circ} \mathrm{C}$. The next day, the slides were dewaxed in xylene, rehydrated in graded alcohol solutions and washed with water. Antigen retrieval was performed using a pressure cooker (Eterna, Nigro, Sao Paulo, Brazil) and $10 \mathrm{mM}$ citrate buffer, $\mathrm{pH}$ 6.0. The samples were quenched with $6 \%$ hydrogen peroxide and incubated overnight at $4{ }^{\circ} \mathrm{C}$ with primary monoclonal antibodies for ER- $\alpha$ (clone SP1, Neomarkers), ER- $\beta$ (clone 14C8, GeneTex) and Ki67 (clone MIB-1, DAKO). The following day, the slides were rinsed with phosphatebuffered saline (PBS) and incubated with the secondary antibody (biotinylated goat anti-mouse/rabbit immunoglobulin) diluted $1: 200$ for $30 \mathrm{~min}$ at $37^{\circ} \mathrm{C}$. The slides were rinsed again with PBS and incubated with streptavidin-biotinylated-peroxidase complex (1:200, 
Duet mouse/rabbit horseradish peroxidase, cat No. 0492; DakoCytomation, Carpinteria CA, USA) for $30 \mathrm{~min}$ at $37^{\circ} \mathrm{C}$. The slides were developed with $0.06 \%$ diaminobenzene as the chromogen with $0.06 \%$ hydrogen peroxide and counterstained with Harris' hematoxylin [27]. Positive and negative control slides were included.

\section{Biomarker scoring}

The results of immunohistochemistry were assessed by 2 investigators (AFL and MM) in a blinded fashion, independently examining the whole slide. In most cases (kappa coefficient $=0.78$ ), the estimations of the 2 investigators were identical, and discrepancies were resolved by joint review of the slides. All slides were examined and scored semi-quantitatively according to Allred's criteria using 2 parameters: the proportion of positive cells and the staining intensity. These parameters were independently recorded for each immunohistochemical reaction. The distribution of the proportional fraction of stained cells on each slide was scored using a scale from 0 to 5 . The intensity of staining was scored from 0 to 3 . The sum of these 2 partial scores resulted in a final score. Zero on this scale indicated that no cells were stained, and scores ranging from 2 to 8 indicated different levels of scoring. All cases with a final score equal to or greater than 3 were considered positive [28,29].

\section{Statistical analysis}

The statistical analysis was conducted by an independent statistician. The hormone therapy for each patient was coded to maintain the blind assessment and avoid bias. The analytical process used the IBM SPSS Statistics 19 software (IBM, USA).

Descriptive statistics were used to summarize the sample characteristics at baseline (mean, standard deviation, minimum, median and maximum). The number of valid observations was used to summarize the numeric variables, and frequency and percentage were used to summarize the categorical variables. The groups were tested for homoscedasticity, also known as homogeneity of variance.

The changes in the ER- $\beta$ scores over time among the groups (anastrozole, tamoxifen and placebo) were evaluated with an ANOVA with repeated measures using rank transformation.

The changes in the Ki67 scores over time and differences among groups (anastrozole, tamoxifen and placebo) were evaluated with an ANOVA with repeated measures for the ER- $\beta$-positive and ER- $\beta$-negative cases. To investigate whether a correlation between ER- $\alpha$ and ER- $\beta$ existed, we calculated the Spearman's correlation coefficient, and graphs of the expression level of each receptor were constructed.

The changes in the Ki67 scores over time and among groups (anastrozole, tamoxifen and placebo) were evaluated for different ER- $\alpha / E R-\beta$ expression ratios with an ANOVA with repeated measures using rank transformation.

The Bonferroni correction (a multiple-comparison test) was used to adjust the $p$ values for multiple testing. All tests were performed with a significance level of $0.05(\mathrm{p} \leq 0.05)$.

\section{Results}

A total of 78 patients were included in our analyses. The statistical analysis showed that there were no significant differences in clinical characteristics between groups (age, age at first menstrual period, age at menopause, number of children, age at birth of first child or tumor size; all p > 0.10); therefore the sample was considered homogeneous. The mean age of the patients included in the study was 65.7 years, with a range of 42-89 years and median of 67 years. The mean age at menopause was 48 years, with a range of 32-60 years and median of 50 years. The average tumor size was $3.9 \mathrm{~cm}$, with a range of $2.5-8.0 \mathrm{~cm}$ and median of $4.0 \mathrm{~cm}$. The majority of patients had stage II carcinoma.

Three tumor samples obtained at the time of diagnosis and/or during definitive surgery had insufficient invasive cancer in the biopsy when re-cut for the ER- $\beta$ study, resulting in a final number of 75 patients for the receptor analysis. Examples of immunoreactivity for ER- $\beta$, ER$\alpha$ and Ki67 are shown in Figure 2. The mean pre- and post-treatment Allred scores for ER- $\beta$ are presented in Table 1 . The frequency of ER- $\beta$ expression did not change after treatment $(\mathrm{p}=0.33)$.

The distribution of patients in each study group and among randomized treatments as well as the number of ER- $\alpha$-positive cases are presented in Table 2.

There was not a significant change of Ki67 levels during neoadjuvant treatment in ER- $\beta$-negative cases $(\mathrm{p}=0.45)$. In these patients, the mean pre- and posttreatment Ki67 scores were 2.3 and 2.2 in the placebo group, 4.2 and 3.5 in the anastrozole group and 4.6 and 3.4 in the tamoxifen group, respectively (Table 3$)$. However, in the ER- $\beta$ positive cases, the anastrozole group $(\mathrm{p}=0.01)$ and tamoxifen group $(\mathrm{p}=0.04)$ presented a significant reduction in post-treatment Ki67 Allred scores compared with baseline. In these cases, the mean pre- and post-treatment Ki67 scores were 3.6 and 4.0 in the placebo group, 4.5 and 3.2 in the anastrozole group and 3.8 and 2.9 in the tamoxifen group, respectively (Table 3 and Figure 3).

Fifty-seven of 78 cases were positive for ER- $\alpha$ (Table 2). The Spearman's correlation coefficients indicated a weak but positive correlation between ER- $\alpha$ and ER- $\beta$ $(\mathrm{r}=0.21, \mathrm{p}=0.08$ in pretreatment and $\mathrm{r}=0.25, \mathrm{p}=0.03$ in post-treatment). Eleven of 47 ER- $\beta$-positive cases were negative for ER- $\alpha$. Unfortunately, the number of cases for each subdivision (groups and according to positive 


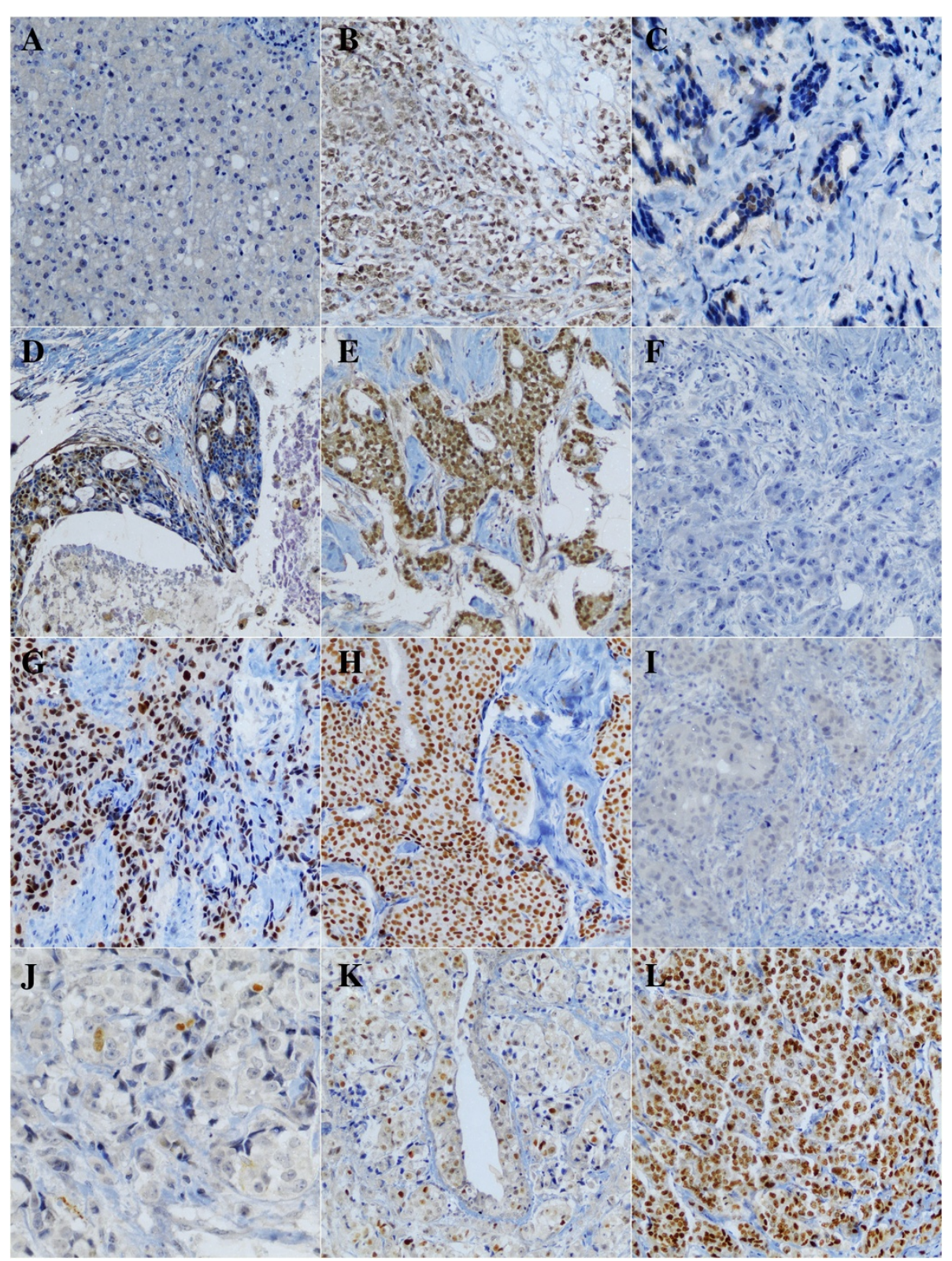

Figure 2 Immunohistochemical staining pattern in BC samples for ER- $\boldsymbol{\beta}$, ER- $\mathbf{a}$ and Ki67. A-E examples of ER- $\beta$ expression: liver as negative control (A), whole section positive control slide (B), Allred score 3 (C), Allred score 5 (D) and Allred score 8 (E). F-H examples of ER-a expression: Allred score $0(\mathbf{F})$, Allred score $6(\mathbf{G})$ and Allred score $8(\mathbf{H})$. I-L examples of Ki67 expression; Allred score 0 (I), Allred score 2 (J), Allred score 5 (K) and Allred score 8 (L).

or negative hormone receptors ER- $\alpha$ and ER- $\beta$ ) was relatively small especially for the ER- $\beta$-negative and ER- $\alpha$ -negative cases, which prevented a separate statistical analysis of Ki67 variation after treatment in each group.

We calculated the ratio of the ER- $\alpha / E R-\beta$ pre-treatment Allred scores and subdivided these patients in 3 groups: ratio $<1$ (patients with a much higher ER- $\beta$ than ER- $\alpha$ score), ratio between 1 and 1.5 (patients with similar scores between the 2 receptors and a slightly higher ER- $\alpha$ score) and ratio $>1.5$ (patients with a much higher ER- $\alpha$ than ER- $\beta$ score). If the denominator (ER- $\beta$ score) of the fraction was zero, we considered as ratio $>1.5$ (patients with a much higher ER- $\alpha$ than ER- $\beta$ score). The exception was when the numerator (ER- $\alpha$ ) was zero too. In this case $(\mathrm{ER}-\alpha=$ zero and ER- $\beta=$ zero), we considered as ratio $<1$. Examples of pretreatment ER- $\alpha / E R-\beta$ ratios and posttreatment Ki67 are shown in Figure 4.

After short-term treatment, there were no significant changes in Ki67 levels in the ratio $<1(\mathrm{p}=0.30)$ and ratio $>1.5(\mathrm{p}=0.41)$ cases. In patients with higher ER- $\beta$ 
Table 1 Changes of ER- $\beta$ scores between treatment groups

\begin{tabular}{|c|c|c|c|c|}
\hline & A & $\mathbf{P}$ & $\mathrm{T}$ & Total \\
\hline \multicolumn{5}{|l|}{ Pre-treatment } \\
\hline Mean \pm SD & $3.21 \pm 2.81$ & $3.21 \pm 2.63$ & $4.17 \pm 2.57$ & $3.51 \pm 2.67$ \\
\hline Median (minimum-maximum) & $3(0-8)$ & $4(0-7)$ & $5(0-8)$ & $4(0-8)$ \\
\hline Total (n) & 24 & 28 & 23 & 75 \\
\hline \multicolumn{5}{|l|}{ Post-treatment } \\
\hline Mean \pm SD & $4 \pm 2.31$ & $2.93 \pm 2.45$ & $5 \pm 2.04$ & $3.91 \pm 2.41$ \\
\hline Median (minimum-maximum) & $4(0-7)$ & $4(0-7)$ & $6(0-8)$ & $4(0-8)$ \\
\hline Total (n) & 25 & 28 & 23 & 76 \\
\hline
\end{tabular}

A: anastrozole group; P: placebo group; T: tamoxifen group; SD: standard deviation.

ANOVA with repeated measures using rank transformation: treatment $(p=0.3312)$ and group $\times$ treatment $(p=0.3052)$.

than ER- $\alpha$ scores (ratio $<1$ ), the mean pre- and posttreatment Ki67 scores were 4.0 and 4.8 in the placebo group, 5.8 and 4.6 in the anastrozole group and 3.8 and 3.5 in the tamoxifen group, respectively. In patients with much higher ER- $\alpha$ than ER- $\beta$ scores (ratio $>1.5$ ), the mean pre- and post-treatment Ki67 scores were 2.7 and 2.6 in the placebo group, 4.0 and 3.5 in the anastrozole group and 4.3 and 3.4 in the tamoxifen group, respectively. However, the patients with an ER- $\alpha / E R-\beta$ score ratio between 1 and 1.5 demonstrated significant differences in Ki67 levels after treatment. For the anastrozole $(p=0.005)$ and tamoxifen $(\mathrm{p}=0.026)$ groups, the Ki67 score was significantly lower after treatment compared with the first biopsy Ki67 score (Figure 5).

\section{Discussion}

The development of new treatments and the assessment of biomarkers to improve $\mathrm{BC}$ patient outcomes require very large randomized adjuvant clinical trials that may extend over several years before the first results are available. Neoadjuvant studies provide an opportunity to integrate the molecular determinants of response and resistance with the clinical response of primary $\mathrm{BC}$ to medical therapy [23,30,31].

The optimum time to evaluate biomarkers for tumor response (apoptosis and proliferation) is not defined. Although cellular changes have been described in vitro after 24 hours of drug exposure, Dowsett et al [23] reported that after two weeks of neoadjuvant treatment of primary breast cancer with anastrozole and tamoxifen, cellular changes are similar to those observed after 12 weeks of treatment. As other similar studies [23,25,28,30], the classical dose of tamoxifen ( $20 \mathrm{mg} /$ day) is enough to reach steady state after 14 days of short-term treatment. The period of 26 days was chosen because this is the average time needed to complete routine preoperative testing in our institutions, justifying the inclusion of ER- $\alpha$-negative patients and the use of placebo without ill consequences to the ER- $\alpha$-positive patients.

Although there is no consensus, the clinicopathologic importance of ER- $\beta$ expression in BC is emerging, including its connection with factors usually associated with a better clinical outcome $[11,17,32,33]$. Until now, data about these favorable prognoses were based on protein studies in BC tissues and cellular experiments [34] or retrospective studies that have assessed ER- $\beta$ expression in relation with the clinical outcome associated with endocrine therapy in BC [35]. In the present study, ER- $\beta$ expression did not change with exposure to any of the tested drugs, but ER- $\beta$-positive postmenopausal patients treated with anastrozole and tamoxifen presented a significant reduction of Ki67 expression after neoadjuvant short-term treatment.

Post-treatment ER- $\beta$ expression did not vary significantly between the 3 groups. This is similar to ER- $\alpha$ expression, which did not vary significantly, as reported in

Table 2 Distribution of patients in the study groups and among randomized treatments

\begin{tabular}{|c|c|c|c|c|c|c|c|c|}
\hline & \multicolumn{2}{|c|}{ A (pre-treatment) } & \multicolumn{2}{|c|}{$\mathrm{P}$ (pre-treatment) } & \multicolumn{2}{|c|}{$\mathrm{T}$ (pre-treatment) } & \multicolumn{2}{|r|}{ Total } \\
\hline & $\mathrm{n}$ & ER-a-positive & $n$ & ER-a-positive & $\mathrm{n}$ & ER-a-positive & $\mathrm{n}$ & ER-a-positive \\
\hline$\overline{\text { ER- } \beta \text {-negative }}$ & 11 & 9 & 12 & 9 & 5 & 3 & 28 & 21 \\
\hline ER- $\beta$-positive & 13 & 9 & 16 & 14 & 18 & 13 & 47 & 36 \\
\hline ER- - /ER- $\beta$ ratio $<1$ & 5 & 2 & 5 & 2 & 8 & 4 & 18 & 8 \\
\hline ER- $\alpha$ /ER- $\beta$ ratio between 1 and 1.5 & 9 & 7 & 7 & 6 & 6 & 5 & 22 & 18 \\
\hline ER- $\alpha /$ ER- $\beta$ ratio $>1.5$ & 10 & 9 & 16 & 15 & 9 & 7 & 35 & 31 \\
\hline
\end{tabular}

A: anastrozole group; P: placebo group; T: tamoxifen group.

ER-a-positive: number of patients in each group considered positive to ER-a (final Allred score equal to or greater than 3). 
Table 3 Allred scores of Ki67 biomarker immunohistochemistry results in ER- $\beta$-negative and ER- $\beta$-positive cases

\begin{tabular}{|c|c|c|c|c|c|c|}
\hline \multirow[t]{2}{*}{ Ki67 } & \multicolumn{2}{|c|}{ Anastrozole (A) } & \multicolumn{2}{|c|}{ Placebo (P) } & \multicolumn{2}{|c|}{ Tamoxifen $(\mathrm{T})$} \\
\hline & Pre-treatment & Post-treatment & Pre-treatment & Post-treatment & Pre-treatment & Post-treatment \\
\hline \multicolumn{7}{|l|}{ ER- $\beta$-negative } \\
\hline Mean \pm SD & $4.2 \pm 1.9$ & $3.5 \pm 2.8$ & $2.3 \pm 1.4$ & $2.2 \pm 1.7$ & $4.6 \pm 1.9$ & $3.4 \pm 2.7$ \\
\hline Median (minimum-maximum) & $4(2-8)$ & $2(0-8)$ & $2(0-4)$ & $2(0-5)$ & $4(2-7)$ & $3(0-7)$ \\
\hline Total (n) & 11 & 11 & 12 & 12 & 5 & 5 \\
\hline \multicolumn{7}{|l|}{ ER- $\beta$-positive } \\
\hline Mean \pm SD & $4.5 \pm 2$ & $3.2 \pm 2.1^{*}$ & $3.6 \pm 1.8$ & $4 \pm 1.6$ & $3.8 \pm 1.8$ & $2.9 \pm 2.1^{* *}$ \\
\hline Median (minimum-maximum) & $4(0-7)$ & $2(0-7)$ & $4(0-6)$ & $4(2-6)$ & $4(0-6)$ & $3(0-7)$ \\
\hline Total (n) & 13 & 13 & 16 & 16 & 18 & 18 \\
\hline
\end{tabular}

SD: standard deviation.

ER- $\beta$-negative: ANOVA with repeated measures: group $(p=0.071)$, treatment $(p=0.084)$ and group $\times$ treatment $(p=0.446)$.

ER- $\beta$-positive: ANOVA with repeated measures: group $(p=0.726)$, treatment $(p=0.036)$ and group $\times$ treatment $(p=0.032)$.

Bonferroni multiple comparison test for ER- $\beta$-positive analysis: group A (pre- $\times$ post-treatment: $p=0.014^{*}$ ), group $P($ pre- $\times$ post-treatment: $p=0.113$ ) and group T (pre- $\times$ post-treatment: $\left.\mathrm{p}=0.046^{* *}\right)$.

the Immediate Preoperative Anastrozole, Tamoxifen, or Combined with Tamoxifen trial [25] and in more recent studies [28]. Thus, post-treatment ER- $\beta$ expression alone does not appear to be an early predictor of response to short-term anastrozole and tamoxifen therapies. In a randomized trial of vorozole versus tamoxifen [36], there was a decrease in ER- $\alpha$ expression with both drugs, and this has also been found in a study comparing letrozole and tamoxifen [24]. However, in stimulation assays, Smollich et al [37] indicated that tamoxifen and fulvestrant increased ER- $\alpha$ expression and left ER- $\beta$ expression unchanged, while AI up-regulated ER- $\beta$ (anastrozole, $\mathrm{p}=0.029$; letrozole, $\mathrm{p}=0.048$ ). These data indicate that SERMs/antiestrogens and AI can exhibit opposing effects on the ER expression of $\mathrm{BC}$ cells, which may contribute to the therapeutic superiority of AI over antiestrogens. Interestingly, it has been found that ER- $\beta$ is significantly upregulated, whereas ER- $\alpha$ is down-regulated in tumors after treatment of premenopausal women with BCs with adjuvant letrozole in combination with gonadotropin-releasing hormone (GnRH) analogues [38]. In addition, patients treated with anastrozole but not with tamoxifen have a significant reduction in PgR expression [25,28,29]. It is likely

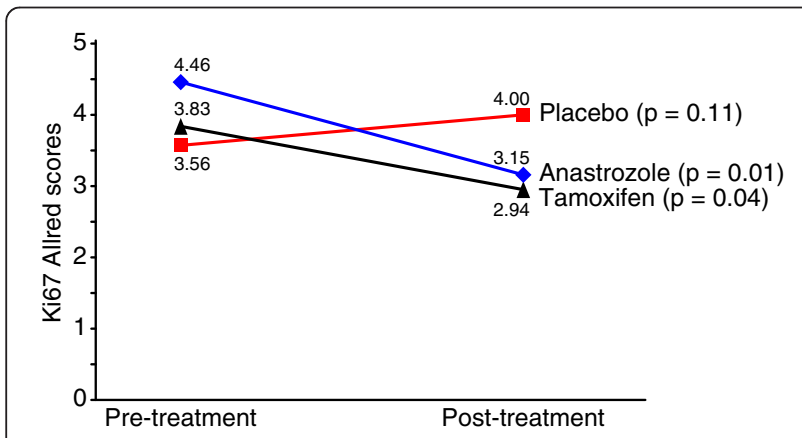

Figure 3 Changes in Ki67 after short-term treatment of ER- $\beta$ -positive breast cancer. that the production of estrogen is consistently blocked and that the expression PgR is significantly reduced by the action of AI.

Short-term changes in Ki67 are not intended to be used for treatment decisions in individual patients. However, they do support the use of this clinical model for the evaluation of new agents before the initiation of large-scale adjuvant trials. Independently of ER- $\alpha$ status, the results from our prospective study demonstrate that ER- $\beta$ - positive BC treated with anastrozole and tamoxifen presents a significant reduction in Ki67 expression after neoadjuvant short-term treatment compared with placebo and ER- $\beta$-negative cases. In a 58 ER- $\alpha$-positive $\mathrm{BC}$ patient study, Mattar et al [28] demonstrated that short-term tamoxifen therapy was not associated with a significant reduction in Ki67 expression. However, some important studies have demonstrated paradoxical Ki67 increases after neoadjuvant endocrine therapy [23,24,39]. Ellis et al [24] observed an increase in Ki67 with treatment in HER1/2-negative cases. The molecular basis for this advantage appears complex but includes a possible tamoxifen agonist effect in ER- $\alpha$-positive BC. In addition, the degree of Ki67 suppression varies markedly between tumors in some trials [25], and this indicates that the degree of estrogenic dependence is highly variable between tumors.

Our data indicate that ER- $\beta$ positivity could predict the tamoxifen effect in $\mathrm{BC}$ treatment with no initial increase of Ki67 (the tamoxifen flare phenomenon). In fact, there is substantial evidence for ER- $\beta$ as a predictor of the tamoxifen endocrine response $[17,40,41]$. Recently, Yan et al [42] analyzed ER- $\beta$ and its co-regulator Steroid Receptor RNA Activator Protein (SRAP) expression in tissue microarrays from a randomized, placebocontrolled trial and found that the benefit was only in the tamoxifen-treated but not in the placebo arm; therefore providing evidence that ER- $\beta$ expression was 


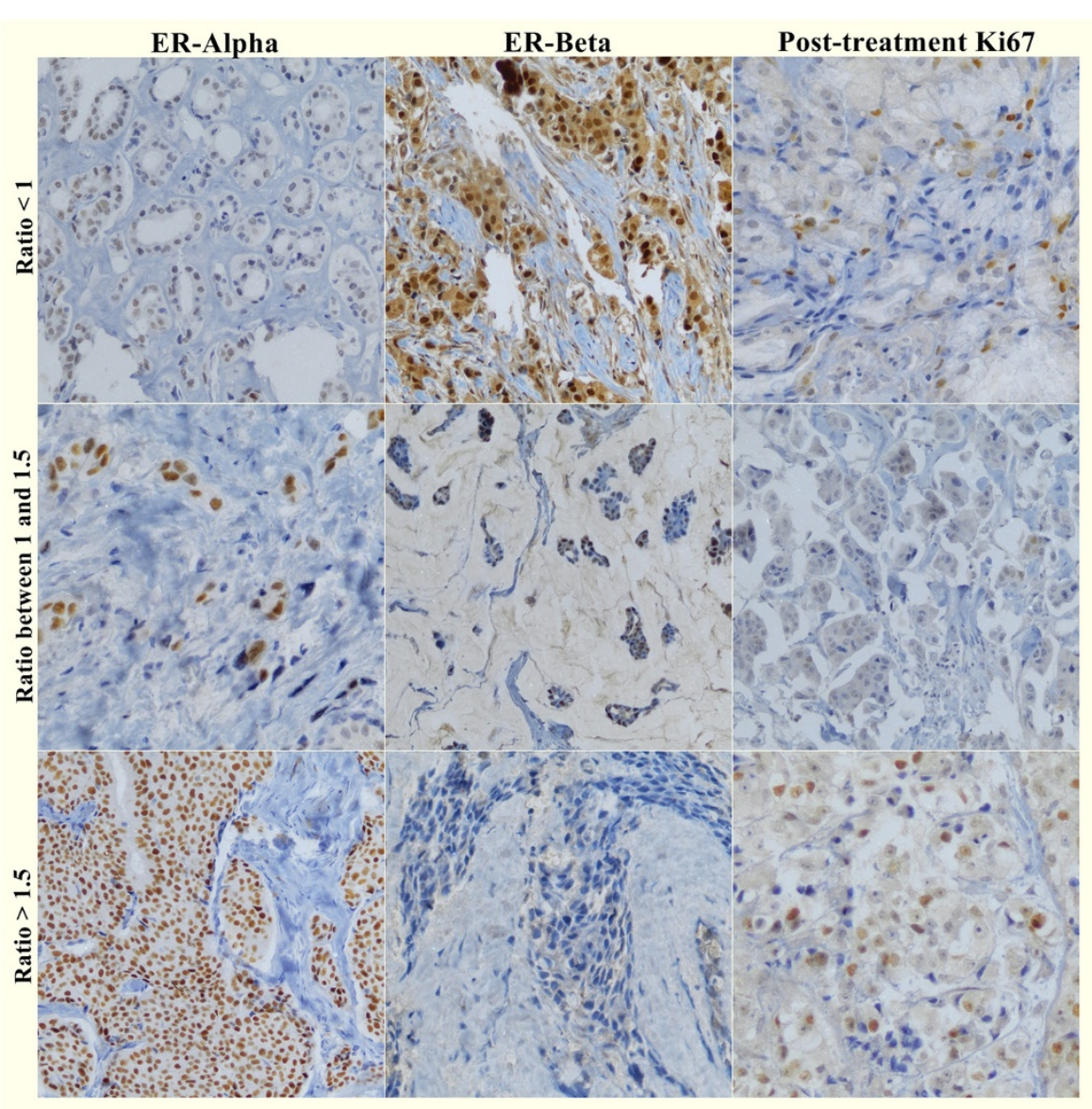

Figure 4 Pretreatment Allred scores ratios of ER-a/ER- $\beta$ and post-treatment Ki67 expression. Immunohistochemical staining showing different examples of ER-a/ER- $\beta$ ratios: Case 2 (ratio < 1) with a poor variation in Ki67 level; Case 37 (ratio between 1 and 1.5) with a significant difference in Ki67 level after treatment and Case 28 (ratio > 1.5) with no significant change in Ki67 expression.

predictive for response to tamoxifen inhibition of tumor growth and survival particularly in ER- $\alpha$-negative premenopausal early BC. Another study indicated that ER- $\beta$ enhances the antiestrogenic actions of endoxifen in $\mathrm{BC}$ cells [43]. Thus, the potential benefit from tamoxifen therapy observed in our clinical study with

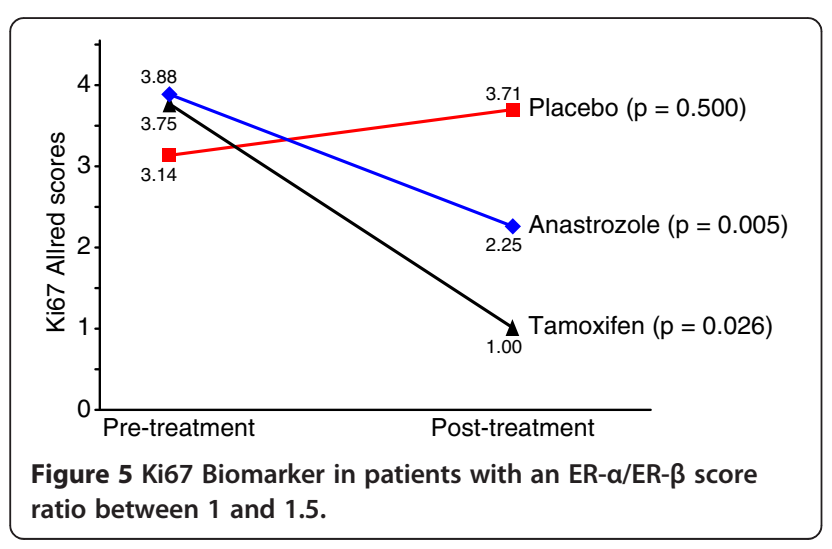

patients whose tumors are ER- $\beta$-positive may be mediated through the actions of endoxifen. In addition, the ability of low endoxifen concentrations to significantly inhibit estrogen-induced gene expression and proliferation in ER- $\beta$-expressing $B C$ cells suggests that the benefits from tamoxifen therapy may still be observed in patients characterized as poor metabolizers based on their Cytochrome P450 2D6 genotype if their tumors are ER- $\beta$-positive [43]. Tamoxifen is an effective drug, but 2 drawbacks are associated with its clinical use: not all ER$\alpha$-positive BCs respond to tamoxifen, and most patients develop resistance to tamoxifen with prolonged use. Given recent insights into the understanding of estrogen signaling and how ER- $\beta$ is involved, these negative aspects of tamoxifen can be understood, and better methods for testing cancers for sensitivity to tamoxifen and for the development of tamoxifen resistance are available [44]. The assessment of pretreatment ER- $\beta$ phenotype and changes in that phenotype with therapy alongside the changes in Ki67, as observed in our data, 
may help establish the mechanisms that contribute to the variable response observed and lead to strategies that may overcome tamoxifen resistance.

The most important question for clinicians is whether the ER- $\beta$ status provides clinically useful information over what is already provided by the traditional ER- $\alpha$ $/ \mathrm{PgR}$ assay. On this matter, there are 2 groups of $\mathrm{BCs}$, one in which ER- $\beta$ is coexpressed with ER- $\alpha$ and the other in which ER- $\beta$ is expressed alone. The first group comprises approximately $59 \%$ of all primary BCs, while the ER- $\beta$ alone-expressing group comprises approximately $17 \%$ [34]. Promising findings in ER- $\beta$-positive/ ER- $\alpha$-negative $B C$ cases have demonstrated that ER- $\beta$ status is a significant prognostic factor in univariate and multivariate analysis [17]. In this study based on the archival material of 442 BCs from women treated with adjuvant tamoxifen, ER- $\beta$ positivity in ER- $\alpha /$ PgR-negatives cases was associated with significantly better survival compared with ER- $\beta$ negative $B C$. In ER- $\alpha$-negative tumors, ER- $\beta$ expression appears to be associated with longer disease-free survival upon endocrine treatment [41]. Some findings also indicate the possibility that ER- $\beta$ expression levels might be especially relevant for prognostic stratification of the ER- $\alpha$-positive/PgR-positive tumors, which have a more favorable natural history [45].

Shortly after the discovery of ER- $\beta$, it was shown that ER- $\beta$ mediates other and opposite effects to those of ER$\alpha$ [46]. Upon ligand activation, the receptors dissociate, change conformation and form functional dimers at specific DNA elements. Depending on the presence of ER- $\alpha$ and ER- $\beta$ in a certain cell, the receptors form functional homo- or heterodimers on promoter elements [40]. ER$\beta$ appears to reduce the cell proliferation induced by ER$\alpha$ activation. Since the first evidence that ER- $\beta$ is an important modulator of proliferation and invasion of $B C$ cells, it has been shown that the ratio of ER- $\alpha / E R-\beta$ expression is higher in $B C$ than normal tissues due to the lower expression of ER- $\beta$, supporting the hypothesis first shown by League et al [47] that the loss of ER- $\beta$ expression could be one of the events leading to the development of $\mathrm{BC}$ tumorigenesis. The reason for this loss of ER- $\beta$ in cancer appears to be the silencing of ER- $\beta$ via promoter methylation $[44,48]$.

The identification of five major variants of ER- $\beta$ ( $\beta 1$, $\beta 2 / c x, \beta 3, \beta 4$ and $\beta 5)$, mainly generated through alternative splicing events, increases the complexity of interpreting the literature data accumulated using only one antibody for immunodetection of ER- $\beta$ expression [49,50]. There is no consensus regarding the function of each variant and contradictory results concerning potential function have been published [51]. It seems that the variant ER- $\beta$ isoforms can modify both ER- $\alpha$ and ER- $\beta 1$ activity when co-expressed. Therefore, differential expression of the ER- $\beta$ variants may play a role in the so-called bi-faceted ER- $\beta$ action and sensitivity to antiestrogens during breast tumorigenesis and breast cancer progression [49]. Our immunostainings were carried out using a monoclonal anti-ER- $\beta$ antibody (clone 14C8 from GeneTex), which is pan-specific for ER- $\beta$ isoforms. Therefore, we evaluated total ER- $\beta$ protein levels by performing immunohistochemistry using this well-characterized antibody, previously shown to be one of the best-performing antibodies for this application [52].

Our data also indicate a weak but positive correlation between ER- $\alpha$ and ER- $\beta$ and demonstrate significant decreases in Ki67 levels after treatment with both anastrozole and tamoxifen only in patients with a ratio of ER- $\alpha / E R-\beta$ Allred scores between 1 and 1.5. No changes in Ki67 levels were observed in patients with higher ER- $\beta$ than ER- $\alpha$ scores $($ ratio $<1$ ) or with much higher ER- $\alpha$ scores than ER- $\beta$ (ratio > 1.5). The effects of hormonal treatment on cell proliferation are apparently dependent on the actual ratio of ER- $\alpha$ /ER- $\beta$ expression levels in these tumors and not only the receptor positivity. Sotoca et al [53] investigated how variable cellular expression ratios of ER- $\alpha$ and ER- $\beta$ modulate the effects on cell proliferation induced by ER- $\alpha$ or ER- $\beta$ agonists, respectively. Consistent with our results, they found the use of ER- $\beta$ protein expression levels as a biomarker in tumor screening, in addition to protein expression levels of ER- $\alpha$, to be a more successful indication of therapeutic responses and course/outcome of the disease in ER-positive tumors [53]. In fact, in vitro studies have indicated that a tamoxifen treatment of ER- $\alpha$ BC cells has an even stronger effect in the presence of ER- $\beta$ [12]. Because ER- $\alpha$ and ER- $\beta$ differ in affinity for promoter elements, this might explain their difference in tamoxifen responses. Estrogen response element activity is repressed by both ER- $\alpha$ and ER- $\beta$ in the presence of tamoxifen, while activator protein 1 (AP-1) responsive elements are activated by both receptors in the presence of tamoxifen. When ER- $\beta$ is expressed in parallel with $E R-\alpha$, which is the case of our patients with a ratio of ER- $\alpha /$ ER- $\beta$ Allred scores between 1 and 1.5, the activation of AP- 1 elements is inhibited by ER- $\beta$ [40,54], and this could play an important role in the behavior of $\mathrm{BC}$ cells in response to tamoxifen. The role of ER- $\beta$ in response to AI therapy is unclear. In a study by Torrisi et al [38], it was found that ER- $\beta$ is significantly up-regulated, whereas ER- $\alpha$ is down-regulated after treatment of 32 premenopausal women with BCs with adjuvant letrozole in combination with a $\mathrm{GnRH}$ analogue. Our study with postmenopausal women treated with anastrozole also demonstrated a decrease in Ki67 levels after treatment with anastrozole only in patients with a ratio of ER- $\alpha / E R-$ $\beta$ Allred scores between 1 and 1.5. It is possible that ER- $\beta$ or its relationship with ER- $\alpha$ is important in the therapeutic response to AI. 
These results support the hypothesis of other authors [35] who have suggested that the assessment of ER- $\beta$ together with ER- $\alpha$ is a better predictor of endocrine responsiveness than ER- $\alpha$ alone. In addition, as some studies have suggested that ER- $\beta$ correlates with and regulates PgR expression together with ER- $\alpha$ [55-57], it is possible that ER- $\beta$ and ER- $\alpha$ could be better biomarkers than ER- $\alpha$ and PgR. It is also possible that the 3 receptors in combination may provide the most precise prediction of endocrine responsiveness.

Our study was hampered by relatively small sample size. The number of cases according to positive or negative hormone receptors (especially for the ER- $\beta$-negative and ER- $\alpha$-negative cases) prevented a separate statistical analysis of Ki67 changes after treatment in each group. A systematic and larger study, taking ER- $\beta$ status into consideration, for patients with different positivity for receptors (ER- $\beta$, ER- $\alpha$ and PgR) could better characterize each cancer and help to optimize adjuvant treatment for BC patients. Some differences of our conclusions compared with other studies should be drawn keeping in mind the large amount of ER- $\beta$ antibodies used in the literature and the various cut points for determining the positivity of ER- $\alpha$ and ER- $\beta$. Some published data on the usefulness of several ER- $\beta$ antibodies for a number of analyses including immunohistochemistry have underscored the marked variations in specificity and likely sensitivity that exist for the different antibodies currently available [58]. In addition, our Brazilian population is one of the most heterogeneous in the world, formed mainly by the admixture between European, African and Native American populations and, more recently, individuals of Asian origins. These racespecific factors may also influence our findings compared with the white population of others studies. Although no studies have examined specifically differences in ER- $\beta$ protein expression with regards to ethnicity, two studies showed that ER- $\beta$ mRNA levels are significantly decreased in ER- $\alpha$-positive BC from African American women [59] and from East Asian women [60]. It should also be noted that the patients enrolled onto this trial represent only a small percentage of our whole postmenopausal BC population treated in our institutions during the entry period. Several studies failed to find significant correlations between ER- $\beta$ expression and patient age [11], however, it may be considered another limitation of our study.

\section{Conclusions}

Our results demonstrated for the first time for neoadjuvant short-term treatment that ER- $\beta$ expression did not change during endocrine treatment and may predict the effects of anastrozole and tamoxifen in postmenopausal $\mathrm{BC}$ patients. These effects of hormonal treatment on cell proliferation appear to be dependent on the ratio of ER- $\alpha / E R-\beta$ expression. This study supports further investigation into whether ER- $\beta$ could be a predictor of endocrine responsiveness or whether the receptor could be used as a target in selected groups of BC.

\section{Abbreviations}

BC: Breast cancer; ER: Estrogen receptor; ER-a: Alpha estrogen receptor; PgR: Progesterone receptor; SERM: Selective estrogen-receptor modulator; Al: Aromatase inhibitor; ER- $\beta$ : Beta estrogen receptor; TMA: Tissue microarray; PBS: Phosphate-buffered saline; GnRH: Gonadotropin-releasing hormone; SRAP: Steroid Receptor RNA Activator Protein; AP-1: Activator protein 1.

\section{Competing interests}

The authors declare no competing interests.

\section{Authors' contributions}

MM contributed to the acquisition of the data, biomarker scoring, analysis/ interpretation of the data, and discussions of the content of the manuscript, composition of the manuscript, and revisions to the manuscript before submission. AM participated in the conception, design, acquisition and analysis/interpretation of data. AFL performed the histology and tissue microarray construction and contributed to biomarker scoring and data interpretation. FAS performed histology and Immunohistochemistry assays. LHG conceived the study and contributed to the study design, study coordination, data analysis/interpretation and manuscript composition. All authors read and approved the final manuscript.

\section{Acknowledgements}

The authors are grateful to Mrs. Silvia Lamas from PGS/Medical Statistics for data management and statistical analysis and Mrs. Suely Nonogaki from the Laboratory of Immunohistochemistry, Adolfo Lutz Institute, São Paulo, Brazil for her excellent technical support of our immunohistochemistry experiments. Additionally, we would like to thank Yong K. Joo, Karine A. Cintra, Alexandre Melitto and Ricardo Gonzales for helping patient data collection.

\section{Funding}

This research did not receive any specific grant from any funding agency in the public, commercial or non-profit sectors.

\section{Author details}

'Senology Discipline, Department of Gynecology, Federal University of Sao Paulo-UNIFESP, R. Botucatu, 740, 04023-900 Sao Paulo, SP, Brazil.

${ }^{2}$ Department of Obstetrics \& Gynecology and Women's Health of Albert Einstein Hospital, Av. Albert Einstein, 627, 05652-900 Sao Paulo, SP, Brazil. ${ }^{3}$ Department of Breast Medical Oncology, Centro de Referência da Saúde da Mulher (CRSM)-Pérola Byington Hospital, Av. Brigadeiro Luis Antonio, 683, 01317-000 Sao Paulo, SP, Brazil. ${ }^{4}$ Department of Pathology, Federal University of Sao Paulo-UNIFESP, R. Botucatu, 740, 04023-062 Sao Paulo, SP, Brazil. ${ }^{5}$ Department of Pathology, AC Camargo Hospital, R. Professor Antonio Prudente, 211, 01509-010 Sao Paulo, SP, Brazil.

Received: 15 April 2013 Accepted: 16 September 2013 Published: 18 September 2013

\section{References}

1. Bray F, McCarron P, Parkin DM: The changing global patterns of female breast cancer incidence and mortality. Breast Cancer Res 2004, 6(6):229-239.

2. Jemal A, Ward E, Thun MJ: Recent trends in breast cancer incidence rates by age and tumor characteristics among U.S. women. Breast Cancer Res 2007, 9(3):R28

3. American Cancer Society: Breast cancer facts \& figures 2011-2012. Atlanta: American Cancer Society, Inc; 2012.

4. Early Breast Cancer Trialists' Collaborative Group: Effects of chemotherapy and hormonal therapy for early breast cancer on recurrence and 15-year survival: an overview of the randomised trials. Lancet 2005, 365(9472):1687-1717. 
5. Hurvitz SA, Pietras RJ: Rational management of endocrine resistance in breast cancer: a comprehensive review of estrogen receptor biology, treatment options, and future directions. Cancer 2008, 113(9):2385-2397.

6. Jones $\mathrm{KL}$, Buzdar AU: A review of adjuvant hormonal therapy in breast cancer. Endocr Relat Cancer 2004, 11(3):391-406.

7. Pearce ST, Jordan VC: The biological role of estrogen receptors alpha and beta in cancer. Crit Rev Oncol Hematol 2004, 50(1):3-22.

8. Shaaban AM, Sloane JP, West CR, Foster CS: Breast cancer risk in usual ductal hyperplasia is defined by estrogen receptor-alpha and Ki-67 expression. Am J Pathol 2002, 160(2):597-604

9. Howell A, Cuzick J, Baum M, Buzdar A, Dowsett M, Forbes JF, Hoctin-Boes G, Houghton J, Locker GY, Tobias JS, et al: Results of the ATAC (Arimidex, Tamoxifen, Alone or in Combination) trial after completion of 5 years adjuvant treatment for breast cancer. Lancet 2005, 365(9453):60-62.

10. Kuiper GG, Enmark E, Pelto-Huikko M, Nilsson S, Gustafsson JA: Cloning of a novel receptor expressed in rat prostate and ovary. Proc Natl Acad Sci U S A 1996, 93(12):5925-5930.

11. Fox EM, Davis RJ, Shupnik MA: ERbeta in breast cancer-onlooker, passive player, or active protector? Steroids 2008, 73(11):1039-1051.

12. Strom A, Hartman J, Foster JS, Kietz S, Wimalasena J, Gustafsson JA: Estrogen receptor beta inhibits 17 beta-estradiol-stimulated proliferation of the breast cancer cell line T47D. Proc Natl Acad Sci U S A 2004, 101 (6):1566-1571.

13. Lazennec G, Bresson D, Lucas A, Chauveau C, Vignon F: ER beta inhibits proliferation and invasion of breast cancer cells. Endocrinology 2001, 142(9):4120-4130.

14. Paruthiyil S, Parmar $H$, Kerekatte V, Cunha GR, Firestone GL, Leitman DC: Estrogen receptor beta inhibits human breast cancer cell proliferation and tumor formation by causing a G2 cell cycle arrest. Cancer Res 2004, 64(1):423-428

15. Rayner $\mathrm{K}$, Chen $Y X$, Hibbert B, White D, Miller H, Postel EH, O'Brien ER: Discovery of $\mathrm{NM} 23-\mathrm{H} 2$ as an estrogen receptor beta-associated protein: role in estrogen-induced gene transcription and cell migration. J Steroid Biochem Mol Biol 2008, 108(1-2):72-81.

16. Hartman J, Lindberg K, Morani A, Inzunza J, Strom A, Gustafsson JA: Estrogen receptor beta inhibits angiogenesis and growth of T47D breast cancer xenografts. Cancer Res 2006, 66(23):11207-11213.

17. Honma N, Horii R, Iwase T, Saji S, Younes M, Takubo K, Matsuura M, Ito Y, Akiyama F, Sakamoto G: Clinical importance of estrogen receptor-beta evaluation in breast cancer patients treated with adjuvant tamoxifen therapy. J Clin Oncol 2008, 26(22):3727-3734.

18. Lindberg K, Helguero LA, Omoto Y, Gustafsson JA, Haldosen LA: Estrogen receptor beta represses Akt signaling in breast cancer cells via downregulation of HER2/HER3 and upregulation of PTEN: implications for tamoxifen sensitivity. Breast Cancer Res 2011, 13(2):R43.

19. Osborne CK: Steroid hormone receptors in breast cancer management. Breast Cancer Res Treat 1998, 51(3):227-238.

20. Hodges-Gallagher L, Valentine CD, El Bader S, Kushner PJ: Estrogen receptor beta increases the efficacy of antiestrogens by effects on apoptosis and cell cycling in breast cancer cells. Breast Cancer Res Treat 2008, 109(2):241-250.

21. Qui WS, Yue L, Ding AP, Sun J, Yao Y, Shen Z, Fan LH: Co-expression of ERbeta and HER2 associated with poorer prognosis in primary breast cancer. Clin Invest Med 2009, 32(3):E250-E260.

22. Goncalves R, Ma C, Luo J, Suman V, Ellis MJ: Use of neoadjuvant data to design adjuvant endocrine therapy trials for breast cancer. Nat Rev Clin Oncol 2012, 9(4):223-229.

23. Dowsett M, Smith IE, Ebbs SR, Dixon JM, Skene A, Griffith C, Boeddinghaus I, Salter J, Detre S, Hills M, et al: Short-term changes in Ki-67 during neoadjuvant treatment of primary breast cancer with anastrozole or tamoxifen alone or combined correlate with recurrence-free survival. Clin Cancer Res 2005, 11 (2 Pt 2):951s-958s.

24. Ellis MJ, Coop A, Singh B, Tao Y, Llombart-Cussac A, Janicke F, Mauriac L, Quebe-Fehling E, Chaudri-Ross HA, Evans DB, et al: Letrozole inhibits tumor proliferation more effectively than tamoxifen independent of HER1/2 expression status. Cancer Res 2003, 63(19):6523-6531.

25. Dowsett M, Ebbs SR, Dixon JM, Skene A, Griffith C, Boeddinghaus I, Salter J, Detre S, Hills M, Ashley S, et al: Biomarker changes during neoadjuvant anastrozole, tamoxifen, or the combination: influence of hormonal status and HER-2 in breast cancer-a study from the IMPACT trialists. J Clin Oncol 2005, 23(11):2477-2492.
26. Urbaniak GC, Plous S: Research randomizer. 3rd edition. 2011

27. Joo YK, Logullo AF, Mattar A, Nonogaki S, Soares FA, Gebrim LH: Wnt pathway is affected by endocrine therapy in breast carcinomas. Basic Appl Pathol 2011, 4(2):38-45.

28. Mattar A, Logullo AF, Facina G, Nonogaki S, Soares FA, Gebrim LH: Shortterm anastrozole therapy reduces $\mathrm{Ki}-67$ and progesterone receptor expression in invasive breast cancer: a prospective, placebo-controlled, double-blind trial. J Cancer Res Clin Oncol 2011, 137(5):897-905.

29. Ellis MJ, Tao Y, Luo J, A'Hern R, Evans DB, Bhatnagar AS, Chaudri Ross HA, von Kameke A, Miller WR, Smith I, et al: Outcome prediction for estrogen receptor-positive breast cancer based on postneoadjuvant endocrine therapy tumor characteristics. J Natl Cancer Inst 2008, 100(19):1380-1388.

30. Dowsett M, Smith IE, Ebbs SR, Dixon JM, Skene A, A'Hern R, Salter J, Detre S, Hills M, Walsh G: Prognostic value of Ki67 expression after short-term presurgical endocrine therapy for primary breast cancer. J Natl Cancer Inst 2007, 99(2):167-170.

31. Ellis MJ: Neoadjuvant endocrine therapy for breast cancer: more questions than answers. J Clin Oncol 2005, 23(22):4842-4844.

32. Skliris GP, Carder PJ, Lansdown MR, Speirs V: Immunohistochemical detection of ERbeta in breast cancer: towards more detailed receptor profiling? Br J Cancer 2001, 84(8):1095-1098.

33. Zhao C, Dahlman-Wright K, Gustafsson JA: Estrogen receptor beta: an overview and update. Nucl Recept Signal 2008, 6:e003.

34. Saji S, Hirose M, Toi M: Clinical significance of estrogen receptor beta in breast cancer. Cancer Chemother Pharmacol 2005, 56(Suppl 1):21-26.

35. Murphy LC, Watson PH: Is oestrogen receptor-beta a predictor of endocrine therapy responsiveness in human breast cancer? Endocr Relat Cancer 2006, 13(2):327-334.

36. Harper-Wynne CL, Sacks NP, Shenton K, MacNeill FA, Sauven P, Laidlaw IJ, Rayter Z, Miall S, Howes A, Salter J, et al: Comparison of the systemic and intratumoral effects of tamoxifen and the aromatase inhibitor vorozole in postmenopausal patients with primary breast cancer. J Clin Oncol 2002, 20(4):1026-1035.

37. Smollich M, Gotte M, Fischgrabe J, Radke I, Kiesel L, Wulfing P: Differential effects of aromatase inhibitors and antiestrogens on estrogen receptor expression in breast cancer cells. Anticancer Res 2009, 29(6):2167-2171.

38. Torrisi R, Bagnardi V, Pruneri G, Ghisini R, Bottiglieri L, Magni E, Veronesi P, D'Alessandro C, Luini A, Dellapasqua S, et al: Antitumour and biological effects of letrozole and GnRH analogue as primary therapy in premenopausal women with ER and PgR positive locally advanced operable breast cancer. Br J Cancer 2007, 97(6):802-808.

39. Ellis MJ, Suman VJ, Hoog J, Lin L, Snider J, Prat A, Parker JS, Luo J, Deschryver K, Allred DC, et al: Randomized phase II neoadjuvant comparison between letrozole, anastrozole, and exemestane for postmenopausal women with estrogen receptor-rich stage 2 to 3 breast cancer: clinical and biomarker outcomes and predictive value of the baseline PAM50-based intrinsic subtype-ACOSOG Z103. J Clin Oncol 2011, 29(17):2342-2349.

40. Hartman J, Strom A, Gustafsson JA: Estrogen receptor beta in breast cancer-diagnostic and therapeutic implications. Steroids 2009, 74(8):635-641.

41. Gruvberger-Saal SK, Bendahl PO, Saal LH, Laakso M, Hegardt C, Eden P, Peterson C, Malmstrom P, Isola J, Borg A, et al: Estrogen receptor beta expression is associated with tamoxifen response in ERalpha-negative breast carcinoma. Clin Cancer Res 2007, 13(7):1987-1994.

42. Yan Y, Li X, Blanchard A, Bramwell VH, Pritchard KI, Tu D, Shepherd L, Myal $Y$, Penner C, Watson PH, et al: Expression of both Estrogen Receptor-beta 1 (ER-beta1) and its co-regulator Steroid Receptor RNA Activator Protein (SRAP) are predictive for benefit from tamoxifen therapy in patients with Estrogen Receptor-alpha (ER-alpha)-Negative Early Breast Cancer (EBC). Ann Oncol 2013, 24(8):1986-1993.

43. Wu X, Subramaniam M, Grygo SB, Sun Z, Negron V, Lingle WL, Goetz MP, Ingle JN, Spelsberg TC, Hawse JR: Estrogen receptor-beta sensitizes breast cancer cells to the anti-estrogenic actions of endoxifen. Breast Cancer Res 2011, 13(2):R27.

44. Warner M, Gustafsson JA: The role of estrogen receptor beta (ERbeta) in malignant diseases-a new potential target for antiproliferative drugs in prevention and treatment of cancer. Biochem Biophys Res Commun 2010, 396(1):63-66

45. Maehle BO, Collett K, Tretli S, Akslen LA, Grotmol T: Estrogen receptor beta-an independent prognostic marker in estrogen receptor alpha and 
progesterone receptor-positive breast cancer? APMIS 2009, 117(9):644-650.

46. Paech K, Webb P, Kuiper GG, Nilsson S, Gustafsson J, Kushner PJ, Scanlan TS: Differential ligand activation of estrogen receptors ERalpha and ERbeta at AP1 sites. Science 1997, 277(5331):1508-1510.

47. Leygue E, Dotzlaw H, Watson PH, Murphy LC: Altered estrogen receptor alpha and beta messenger RNA expression during human breast tumorigenesis. Cancer Res 1998, 58(15):3197-3201.

48. Suzuki F, Akahira J, Miura I, Suzuki T, Ito K, Hayashi S, Sasano H, Yaegashi N: Loss of estrogen receptor beta isoform expression and its correlation with aberrant DNA methylation of the 5'-untranslated region in human epithelial ovarian carcinoma. Cancer Sci 2008, 99(12):2365-2372.

49. Leygue $E$, Murphy $L C: A$ bi-faceted role of estrogen receptor beta in breast cancer. Endocr Relat Cancer 2013, 20(3):R127-R139.

50. Murphy $L C$, Leygue $E:$ The role of estrogen receptor-beta in breast cancer. Semin Reprod Med 2012, 30(1):5-13.

51. Leung YK, Mak P, Hassan S, Ho SM: Estrogen receptor (ER)-beta isoforms: a key to understanding ER-beta signaling. Proc Natl Acad Sci U S A 2006, 103(35):13162-13167.

52. Skliris GP, Parkes AT, Limer JL, Burdall SE, Carder PJ, Speirs V: Evaluation of seven oestrogen receptor beta antibodies for immunohistochemistry, western blotting, and flow cytometry in human breast tissue. J Pathol 2002, 197(2):155-162.

53. Sotoca AM, van den Berg H, Vervoort J, van der Saag P, Strom A, Gustafsson JA, Rietjens I, Murk AJ: Influence of cellular ERalpha/ERbeta ratio on the ERalpha-agonist induced proliferation of human T47D breast cancer cells. Toxicol Sci 2008, 105(2):303-311.

54. Maruyama S, Fujimoto N, Asano K, Ito A: Suppression by estrogen receptor beta of AP-1 mediated transactivation through estrogen receptor alpha. J Steroid Biochem Mol Biol 2001, 78(2):177-184.

55. Jarvinen TA, Pelto-Huikko M, Holli K, Isola J: Estrogen receptor beta is coexpressed with ERalpha and PR and associated with nodal status, grade, and proliferation rate in breast cancer. Am J Pathol 2000, 156(1):29-35.

56. Murphy LC, Leygue E, Niu Y, Snell L, Ho SM, Watson PH: Relationship of coregulator and oestrogen receptor isoform expression to de novo tamoxifen resistance in human breast cancer. Br J Cancer 2002, 87 (12):1411-1416.

57. Murphy LC, Peng B, Lewis A, Davie JR, Leygue E, Kemp A, Ung K, Vendetti $M$, Shiu R: Inducible upregulation of oestrogen receptor-beta1 affects oestrogen and tamoxifen responsiveness in MCF7 human breast cancer cells. J Mol Endocrinol 2005, 34(2):553-566.

58. Skliris GP, Leygue E, Watson PH, Murphy LC: Estrogen receptor alpha negative breast cancer patients: estrogen receptor beta as a therapeutic target. J Steroid Biochem Mol Biol 2008, 109(1-2):1-10.

59. Poola I, Clarke R, DeWitty R, Leffall LD: Functionally active estrogen receptor isoform profiles in the breast tumors of African American women are different from the profiles in breast tumors of Caucasian women. Cancer 2002, 94(3):615-623.

60. Hsiao WC, Cho WC, Lin PW, Lin SL, Lee WY, Young KC: Quantitative profile of estrogen receptor variants/isoforms in Taiwanese women with breast cancer. Eur J Surg Oncol 2006, 32(5):492-497.

doi:10.1186/1471-2407-13-425

Cite this article as: Madeira et al.: Estrogen receptor alpha/beta ratio and estrogen receptor beta as predictors of endocrine therapy responsiveness-a randomized neoadjuvant trial comparison between anastrozole and tamoxifen for the treatment of postmenopausal breast cancer. BMC Cancer 2013 13:425.

\section{Submit your next manuscript to BioMed Central and take full advantage of:}

- Convenient online submission

- Thorough peer review

- No space constraints or color figure charges

- Immediate publication on acceptance

- Inclusion in PubMed, CAS, Scopus and Google Scholar

- Research which is freely available for redistribution 